\title{
HORIZONTAL INNOVATION AND AMBIDEXTROUS ORGANIZATION: A NEW INNOVATION MODEL APPLIED IN A MATURE INDUSTRIAL COMPANY
}

\author{
INOVAÇ̃̃O HORIZONTAL E ORGANIZAÇ̃̃O AMBIDESTRA: UM NOVO MODELO DE INOVAÇÃO APLICADO \\ EM UMA EMPRESA DE UMA INDÚSTRIA MADURA
} INNOVACIÓN HORIZONTAL Y ORGANIZACIÓN AMBIDIESTRA: UN NUEVO MODELO DE INNOVACIÓN
APLICADO EN UNA EMPRESA DE UNA INDUSTRIA MADURA

Antonio Carlos Teixeira Alvares ${ }^{1}$

(iD) José Carlos Barbieri ${ }^{2}$

Dafne Oliveira Carlos de Morais ${ }^{3}$

Cite as - American Psychological Association (APA)

Alvares, A. C. T., Barbieri, J. C., \& Morais, D. O. C. (2021, Sept./Dec.). Horizontal innovation and ambidextrous organization: a new innovation model applied in a mature industrial company. International Journal of Innovation - IJI, São Paulo, 9(3), 588-621. https://doi.org/10.5585/iji.v9i3.19012.

\begin{abstract}
Objective of the study: Analyze how Horizontal Innovation enables a company to produce radical and incremental innovations, making it ambidextrous.

Methodology/approach: The research is a case study at a mature Brazilian company that puts Horizontal Innovation based on its Employee Suggestion System (ESS) into practice. A total of 18 interviews were conducted, including: all 4 directors and all 10 managers of the organization, in addition to 2 coordinators and 2 researchers.

Originality/Relevance: The paper creates and defines the concept of Horizontal Innovation: a type of innovation that originates from all employees, usually stemming from an ESS. The study shows, based on continual ESS operations, how a company can achieve ambidexterity and systematically produce incremental, radical products and processes.

Main results: ESS produces radical innovations as well as incremental ones, although the latter occur more frequently, and lead to Horizontal Innovations. The systematic search for Horizontal Innovations paves the way for a company to become ambidextrous, promoting, with the same competence, these two types of innovation.

Theoretical/methodological contributions: The study contributes to the debate that defends the viability of innovative ambidexterity, and to new insights that clarify how a culture that stimulates ambidexterity can influence the ambidextrous behavior of employees through Horizontal Innovation Practical implications: A new type of innovation is proposed and described, reinforcing the value of an ESS as an important management tool. The case enables comparisons and contrasts with others for best practices benchmarking.
\end{abstract}

Keywords: Horizontal innovation. Incremental innovation. Radical innovation. Suggestion systems. Internal innovation milieu. Ambidextrous organization.

\footnotetext{
${ }^{1}$ PhD Student in Business Administration, FGV EAESP. São Paulo - SP, Brazil. teixeira@ actapar.com.br

${ }^{2} \mathrm{PhD}$ in Business Administration, FGV EAESP. São Paulo - SP, Brazil. jose.barbieri@fgv.br

${ }^{3} \mathrm{PhD}$ in Business Administration, Centro Universitário FEI. São Paulo - SP, Brazil. dafne.morais@ fei.edu.br
} 


\section{Resumo}

Objetivo do estudo: Analisar como a Inovação Horizontal permite que uma empresa produza inovações radicais e incrementais, tornando-se ambidestra.

Metodologia/abordagem: A pesquisa é um estudo de caso em uma empresa brasileira madura que coloca em prática a Inovação Horizontal baseada em seu Sistema de Sugestão de Funcionários (SSF). Foram realizadas 18 entrevistas, sendo: todos os 4 diretores e todos os 10 gerentes da organização, além de 2 coordenadores e 2 pesquisadores.

Originalidade/Relevância: $\mathrm{O}$ artigo cria e define o conceito de Inovação Horizontal: um tipo de inovação que se origina de todos os funcionários, geralmente decorrentes de um SSF. O estudo mostra, com base em operações contínuas de SSF, como uma empresa pode atingir a ambidestria e produzir sistematicamente produtos e processos incrementais e radicais.

Principais resultados: SSF produz inovações radicais, bem como inovações incrementais, embora as últimas ocorram com mais frequência e conduzam a inovações horizontais. A busca sistemática por inovações horizontais abre caminho para que uma empresa se torne ambidestra promovendo com a mesma competência esses dois tipos de inovação.

Contribuições teórico-metodológicas: $\mathrm{O}$ estudo contribui para o debate que defende a viabilidade da ambidestria inovadora e para novos insights que esclareçam como uma cultura que estimula a ambidestria pode influenciar o comportamento ambidestro dos colaboradores por meio da inovação horizontal

Implicações práticas: Um novo tipo de inovação é proposto e descrito, reforçando o valor do Sistema de Sugestão de Funcionários como uma ferramenta de gestão relevante. O caso permite comparações e contrastes com casos para benchmarking de melhores práticas.

Palavras-chave: Inovação horizontal. Inovação incremental. Inovação radical. Sistemas de sugestão. Meios internos de inovação. Organização ambidestra.

\section{Resumen}

Objetivo del estudio: Analizar como la Innovación Horizontal permite a una empresa producir innovaciones radicales e incrementales, volviéndose ambidiestra

Metodología/enfoque: La investigación es un estudio de caso en una empresa brasileña madura que pone en práctica la innovación horizontal basada en su Sistema de Sugerencias de Empleados (SSE). Se realizaron un total de 18 entrevistas, incluyendo: los 4 directores y los 10 gerentes de la organización, además de 2 coordinadores y 2 investigadores.

Originalidad / Relevancia: El documento crea y define el concepto de Innovación Horizontal: un tipo de innovación que se origina en todos los empleados, generalmente derivada de un SSE. El estudio muestra, basado en las operaciones continuas de SSE, como una empresa puede lograr ambidestreza y producir sistemáticamente productos y procesos incrementales y radicales.

Resultados principales: SSE produce tanto innovaciones radicales como innovaciones incrementales, aunque estas últimas ocurren con mayor frecuencia y conducen a innovaciones horizontales. La búsqueda sistemática de innovaciones horizontales allana el camino para que una empresa se convierta en ambidiestra promoviendo con la misma competencia estos dos tipos de innovación.

Aportes teóricos/metodológicos: El estudio contribuye al debate que defiende la viabilidad de la ambidestreza innovadora y a nuevas percepciones que aclaren cómo una cultura que estimula la ambidestreza puede influir en el comportamiento ambidiestro de los empleados a través de la innovación horizontal.

Implicaciones prácticas: Se propone y describe un nuevo tipo de innovación, reforzando el valor del Sistema de Sugerencias del Empleado como herramienta de gestión relevante. El caso permite comparaciones y contrastes con casos de evaluación comparativa de mejores practices.

Palabras clave: Innovación horizontal. Innovación incremental. Innovación radical. Sistemas de sugerencia. Medios internos de innovación. Organización ambidiestra. 


\section{Introduction}

The main importance of innovations, recognized and esteemed within the corporate environment in general, refers to the introduction of major innovations, which engender a significant impact on the economic environment, referred to as radical innovations. Those with lesser degrees of novelty, incremental innovations, enable improvement of existing products and processes resulting from, as a rule, knowledge within the production operations environment. These innovations have received little attention in works covering this topic, although they have played a central role in literature discussing quality and continue to do so.

Given the enormous difference between these two types of innovation, there are those who have suggested that a simultaneous focus on both could jeopardize companies seeking to gain a competitive edge (Peters, 1998; Pagel \& Wu, 2001). In opposition to this argument, the ambidextrous company concept, which arose in the 1970s, prompted a debate regarding the two types of innovation, radical and incremental, construing them as complementary (Lawson \& Samson, 2001; Castellaci, 2008; Kortmann et al., 2014). Some important authors, such as Tushman and O'Reilly (2004, 2013), demonstrated that innovative organizations, those that achieve innovations on a highly frequent basis, operate proficiently on both incremental and radical innovations.

Silveira-Martins et al. (2015) carried out a bibliometric analysis on the ambidexterity theme, and pointed out that, although many researches have already been conducted, the question of how companies can maintain the balance between exploration and exploitation is still pending. Pertusa-Ortega et al. (2020) also synthesized knowledge about organizational ambidexterity through a systematic literature review. The authors stated that, at the individual level, scholars use the term ambidexterity relating to different tensions or conflicting demands Among those tensions, most papers still focused on the one between the exploration of new knowledge and the exploitation of current capabilities (Kobarg et al., 2017; Rosing \& Zacher, 2017). They suggested analyzing the relationship between the influence of ambidextrous orientation on ambidextrous behavior, and the effect of ambidextrous behavior on individual ambidextrous performance.

This paper seeks to contribute to the debate that defends the viability of innovative ambidexterity (i.e., that an organization can achieve radical and incremental innovations at the same time) and for new insights that clarify how a culture that stimulates ambidexterity can influence the ambidextrous behavior of employees, which in turn generates performance in terms of suggestions and implementations of both radical and incremental innovations. In 
addition to the radical-incremental innovation dichotomy, this paper presents empirical evidence for a new innovation concept, entitled Horizontal Innovation, defined as a set of innovations that arise from all the people in an organization, especially those on the front line. The degree of innovation novelty does not matter for this concept, but rather the origin, i.e., any person who works for the organization, regardless of position.

Horizontal innovations, owing to their origins, and especially the fact that the front line is usually the main source of innovation, create an expectation that these would be confused with incremental ones, since these, in general, would arise from the knowledge of people performing their routine tasks, while radical innovations would arise from specifically dedicated operations such as R\&D. In addition to creating and describing the concept of Horizontal Innovation, the study demonstrates, based on continual Employee Suggestion System - (ESS) operations, how a company can achieve ambidexterity and systematically produce incremental, radical products and processes.

There are some other definitions of Horizontal Innovation, one of them used by Von Hippel (2002) to identify the normal knowledge and technology transfer from one company to another usually within the same business sector, instead of inventing something new. However, in the specialized literature, the term to identify the democratization of innovation arising from all employees was not found. In this sense, the purpose of this study is to analyze how Horizontal Innovation enables a company to produce radical and incremental innovations, transforming itself into an ambidextrous company.

In addition to this introductory section, this article reviews the literature on innovation, the types of innovation and ambidexterity. This section also focuses on the Horizontal Innovation concept, since it deals with a new topic in the innovation literature, and, as mentioned, it needs detail given that it could be confused with incremental innovation. Afterward, the methodology is presented, explaining the adoption of a qualitative approach, chosen to help understand and explain a social phenomenon with the least possible distance from its natural environment (Merriam, 1998), through a case study strategy. The case study was used because innovation and organizational ambidexterity continue to be contemporary issues, long recognized as important maturity factors as shown by Paiva (2019). Moreover, the Horizontal Innovation concept is a recent creation, which is the reason why this element is nearly non-existent in the academic literature.

This case study investigates Brasilata S/A Metal Packaging, a steel packaging production company. It was selected according to theoretical sampling, and it meets the single 
case study criterion since the case is outstanding domestically and internationally as an innovative enterprise according to the description above, despite being engaged in a mature manufacturing sector. The innovative characteristic of the company is its suggestion system, one of the best in the world in its business area, according to the Robinson and Schroeder (2014) poll, among others.

In the next section, the findings of the case study are presented and analyzed in comparison to the literature. As its main contributions, this paper strengthens the literature stream that advocates the complementarity of radical and incremental innovations, and expands the types of innovation, introducing the concept of Horizontal innovation. In addition, the paper contributes to the practice by providing evidence of how to obtain competitive advantages even in a mature market through Horizontal Innovation, reinforcing the advantages of an innovative culture. The research also highlights for managers the potential of implementing an ESS as a means of achieving not only incremental, but also radical innovations. The main findings of the paper open lines of research that allow linking innovation performance with models, schemes and/or styles of organizational development.

\section{Theoretical reference framework}

Innovation is highly important to companies and society, so much so that, over time, it has drawn the attention of scholars from diverse areas, giving rise to an array of definitions and concepts. The Oslo Manual, created by the OECD for the purpose of standardizing the data regarding innovation, rendering them reliable and comparable, defines innovation as: "a new or improved product or process (or combination thereof) that differs significantly from the unit's previous products or processes and that has been made available to potential users (product) or brought into use by the unit (process). (OECD \& EUROSTAT, 2018, p.60).

Since this paper focuses on Horizontal Innovations that arise from everyone's ideas, especially those of frontline personnel, it gives preference to the definitions focused on the innovation process. In this regard, Van de Vem, Angle and Poole (2000) defined innovation as the introduction of a new idea. Gundling (2000) defined it as new ideas plus actions or implementations that result in improvements, gains or profits. An Innovation Forum from a Brazilian business school called FGV/EAESP gave it an equation format, namely: Innovation $=$ idea + implementation + result $($ Barbieri \& Álvares, 2004, p. 41).

According to the aforementioned equation, the origins of innovations are ideas, which, once implemented, generate expected results. According to Barbieri and Alvares (2004), there 
will only be one innovation if none of the terms of the above equation is omitted. The last term of the equation demonstrates that innovation must necessarily achieve the desired results for the innovative organization. In the corporate environment, the most highly anticipated results are economic, such as production cost reduction, increased demand, substitution of obsolete products, entry to new markets, improvement in work conditions, to name a few. Therefore, all innovations refer to one or more ideas implemented successfully, even if short-lived, thus, the expression, "failed innovation" would have no significance according to the above definition.

\subsection{Radical and incremental innovations}

The specialized literature presents a variety of criteria for classifying innovations. One of these is the degree of novelty contained in the results. This classification takes two basic types of innovation into consideration, the radical and the incremental, the latter containing a low degree of novelty whereas the former contains a high degree. However, the term, "radical" can refer to an innovation that causes a "significant impact in a market and on the economic activity of companies in this market," as defined in the Oslo Manual (OECD \& EUROSTAT, p. 47). The Manual cites as examples innovations that change the structure of a market, create new markets or render existing products obsolete.

In view of the previous equation, a radical innovation is one that presents significant results. However, how significant should the result be for a given innovation to be declared radical? For Gundling (2000), 3M classifies more radical innovations, either as type A, which gives rise to new businesses or industries, or type $\mathrm{B}$, which changes the competitive base, creating a new competitive position or niche in the established field. In addition to these two types of innovation, $3 \mathrm{M}$ also uses the type $\mathrm{C}$ classification to denote extension of the company's current product line, and, as such, is strictly aligned to explicit consumer necessities, albeit an incremental innovation.

Incremental innovations are improvements that add minor novelty to existing products and known processes. The Oslo Manual gives little importance to this type of innovation, due to the fact it was designed to guide the data collection about investments in innovative activities in OECD countries, where the largest amount of resources invested in innovations based on new knowledge is concentrated, and, therefore, with a greater degree of novelty. Incremental innovation generally results from routine production and marketing activities, to which no specific resources are usually allocated. According to the Oslo Manual, such innovation is more important for countries outside the OECD and for low and medium technology industries 
However, both radical as well as incremental innovations are important to a company, each one fulfilling a different function in the enterprise: radical innovations are associated with the company's strategic positioning in relation to the markets in which they engage or intend to engage, while incremental innovations relate to operational efficiency (Lawson and Samson, 2001).

Incremental innovations have been embraced in texts concerning quality, under the generic heading of improvements and continual improvement. An improvement is a change, which, once implemented generates a result, although its impact may be minor. Continual improvement is the systematic implementation of improvements or, according to ISO (2015, p. 6): "recurring activity to increase performance," understood as a "measurable result." Incremental ones involve lower risks and require less effort in planning and execution. They increase the efficiency over the short term by reducing costs, improving products and working conditions, and providing ready responses to customers.

Radical innovation presupposes allocation of specialized resources, such as an R\&D center or product development department, in which specially hired professionals work to produce knowledge and put it into practice, while incremental innovation, in general, is conducted in a company's operations environment. According to Sheng and Chien (2016), radical innovation requires development of resources and exclusive benefits superior to those found in existing products and markets.

\subsection{Ambidexterity}

In the past, some well-known authors criticized incremental type strategy, based on the supposition that continual improvement of processes would work against radical innovations. "Incrementalism is innovation's worst enemy," states Tom Peters (Peters, 1997, p.26), an influential consultant to large-scale companies, recalling the lessons of Nicholas Negroponte, a researcher at the MIT Media Lab. The argument is that the preoccupation with the operational efficiency would move the focus away from competitive positioning strategies to gain new markets with innovative products. Seeking operational efficiency, i.e., improving that which is already being done, could consume resources for competitive strategies that would create new markets and products. Aiming at operational efficiency is based on incremental innovations, for which their preferred instrument is to criticize the endeavors to improve efficiency, ending up adversely affecting innovation. 
The argument that operational efficiency and, therefore, incremental innovations compete with competitive strategies, and radical innovations support them, was contested at the beginning of the first decade of 2000 . The capacity of organizations that systematically perform incremental, radical innovations was analyzed by Lawson and Samson (2001), Castellaci (2008), Scandelari and Cunha (2013), Kortmann et al. (2014), Kortmann (2015), Cocci (2017), Bouncken et al. (2018), to name a few. Lawson and Samsom (2001), for example, argued that innovative organizations take care of the day-to-day or mainstream objectives as well as radical innovations demanded by the long-term outlook or newstream. According to them, innovative organizations adopt an integrated model between mainstream and newstream. These organizations do not produce innovations solely by scientists in laboratories. On the contrary, incremental, radical innovations permeate the entire organization.

These organizations were denominated "ambidextrous", the same word used to describe a person able to use both hands equally well. Scott (2014) demonstrated that this concept arose in 1976 based on the work by Robert Duncan. Since that time, this concept has been widely used in a range of corporate interest areas, especially in innovation management.

There are two central concepts to understanding ambidexterity: exploration and exploitation (Koryak et al., 2018). March (1991) explains the subject in a seminal article that exploration includes catchall terms such as, search, variation, risk taking, experimentation, game, flexibility, discovery and innovation. Exploitation includes concepts such as refinement, choice, production, efficiency, selection, implementation, execution. In other words, exploration is the search for new knowledge and opportunities, while exploitation is the use and refinement of internal company knowledge. Thus, exploration relates to radical innovation, while exploitation references incremental innovation (Koryak et al., 2018).

Tushman and O'Reilly III (2004) believe that ambidextrous organizations are those that manage to gain competitive advantages producing radical and incremental innovations simultaneously. In their view, some companies have had a great deal of success exploiting the present and exploring the future, and, upon in-depth examination, verify that they share important traits. Specifically, they separate new exploratory units from traditional exploitative ones, which enables differentiation of processes, structures and cultures. Tidd and Benssant (2015) affirmed that the challenge to innovative organizations is to develop ambidextrous capacity to manage both radical as well as incremental innovations.

The balanced, strategic use of exploitation and exploration has been the subject of many recent studies, such as that by Scott (2014), mentioned above, which introduces the concept of 
coordination as a dimension of ambidexterity, while a strategic mechanism to monitor exploration and exploitation operations to assure that neither one is overly stressed. Ajayi et al. (2017) proposed the concept of employee ambidexterity, including two dimensions (i.e., employee passive and active ambidexterity). The passive concept describes the employee's propensity to exploit existing opportunities and explore new opportunities simply by following organizational procedures. On the other hand, the active concept comments on the employees' tendency to seek novel means to engage in exploitation and exploration activities outside organizational rules and procedures.

Kang Hwang (2019) showed that the balance between radical and incremental innovation is an essential part of the ambidextrous use of exploratory and exploitative strategies. Based on a study of 680 Korean companies, this writer showed the importance of a balance between radical and incremental innovations, including small and medium size companies within the open innovation context.

Pertusa-Ortega et al. (2020) also synthesized knowledge about organizational ambidexterity through a systematic literature review. The authors stated that, at the individual level, scholars use the term ambidexterity relating to different tensions or conflicting demands (e.g. flexibility versus efficiency in workplaces (Yu et al., 2018), adaptability versus alignment (Birkinshaw \& Gibson, 2004), creativity versus attention to detail (Sok \& O'Cass, 2015), sale of existing and new products (Van der Borgh et al., 2017)). The authors indicated that, among those tensions, most papers still focused on the one between the exploration of new knowledge and the exploitation of current capabilities (Kobarg et al., 2017; Rosing \& Zacher, 2017). As for research opportunities to refine the topic, Pertusa-Ortega et al. (2020) suggested analyzing the relationship between the influence of ambidextrous orientation on ambidextrous behavior, and the effect of ambidextrous behavior on individual ambidextrous performance.

Koryak et al. (2018) investigated ambidexterity antecedents, under the lenses of an attention-based view of the firm (ABV). Ambidexterity has also been studied in the field of knowledge management, as shown by Chen et al. (2018) and Le et al. (2020), a field in which there is strong interaction with innovation management. Contextual ambidexterity is in evidence (Wolf, 2019), as the capacity to simultaneously demonstrate exploration and exploitation in each entity of an organization (Gibson \& Birkinshaw, 2004). Considering that innovation is strengthened by removing internal organizational barriers, contextual ambidexterity is a crucial capacity of organizations, and enables them to maintain current business activities while engaging in innovative activities (Wolf, 2019). 


\subsection{Horizontal innovation}

Horizontal Innovation should not be confused with incremental innovation. It does not deal with a classification based on the degree of novelty or the impact on a company or market. Its concept relates to the way in which ideas arise and are implemented. The word "horizontal" in the expression "Horizontal Innovation" is in contraposition to the word "vertical", a world hidden in texts concerning innovation management. Even without explicitly mentioning it, its meaning is perceived in academic innovation management literature and in the statements made by practitioners, since are vertical structures that support the innovation processes dealt with in related literature, which, as mentioned previously, emphasized radical innovation.

Development of this specialized management arises from radical innovation characteristics, since they require an intense, complex division of operational and administrative work. The innovation management models centered on radical innovations rely on hierarchical schemes involving different segments of the organization at a variety of decision-making levels of the organization, and, therefore, differ from Horizontal Innovation for which decisions are close to the idea generators.

The results of innovation, the third term of the equation mentioned in Section 2, may have a high or low economic impact; they could be results that strengthen the operational efficiency or competitive strategic positioning of the company. The expression Horizontal Innovation with the meaning of innovation from all employees was used by Álvares (2017-2). Horizontal Innovation is defined as arising from all the people in the organization, especially those on the front line (the factory floor workers in the case of manufacture), driven by an internal innovative environment intentionally created, as will be seen in the next section.

In other words, Horizontal Innovation is the process of innovation democratization, based on the gathering of ideas from all related persons in any company area - in a perspective analogous to crowdsourcing (Howe, 2006; Estellés-Arolas \& González-Ladrón-De-Guevara, 2012), but circumscribed to the company's boundaries, and not just those created specially to foment innovation R\&D, Project Development or Marketing.

Melton and Hartline (2015) suggested that use a detailed but flexible development process and provide extensive opportunities for interaction of customers, frontline employees, and cross-functional teams. Bruneel et al. (2012) discussed how the success of radical innovation projects depends on the commitment of executive management, the head of the innovation role, and the selection and reward mechanisms for R\&D employees. 
The expression Horizontal Innovation with the meaning of innovation from all employees was used by Alvares (2017) and Robinson and Schroeder (2014), who mentioned the importance of gathering ideas from employees, and gave space to the comparative analysis between quality management and innovation, presenting empirical cases.

The implementation of the so-called Japanese industrial techniques has led to the democratization of quality management functions, which, in turn, have become the responsibility of all operators, especially those on the factory floor. It was only upon this modification that the techniques such as just in time, kaizen and lean production became common in the West. With the development of these industrial techniques, especially the Toyota Production System, the systems for gathering ideas from all persons (kaizen type systems) became an important part of a new management concept under which quality is no longer the responsibility of the technical areas, but becomes the responsibility of all, especially the front line (Skarzynsky \& Gibson, 2008).

Innovations arising from all the employees of an organization are, for the large part, incremental, and the way they are gathered, especially in the kaizen-type suggestion systems, have been widely studied by quality experts and practitioners. Gibson and Skarzynsky (2008) and Robinson and Schroeder (2016) mentioned the importance of gathering ideas from employees and gave space to comparative analysis between quality management and innovation, presenting empirical cases. However, these systems are barely mentioned in studies regarding innovation and innovation management because they are focused on innovations that have a high degree of novelty, normally arising from the R\&D and Marketing areas (Barbieri and Alvares, 2005), as mentioned.

Although focused on incremental innovations, high-performance suggestion systems have also recorded radical innovation. One example is Google, where winning products such as Gmail arose from the internal suggestion system (Edelman and Eisenmann, 2011). Radical innovation cases, which create a new industry (type A as shown in Section 2.1), resulting from the idea gathering system are rarer. However, they cannot be discounted because there are records of them in several companies. For example, according to Gundling (2000), reflective tape, Scotchguard and post-it are innovations achieved by $3 \mathrm{M}$ based on ideas from their employees. 


\subsection{Employee Suggestion Systems - ESS}

ESSs have drawn little attention in the literature on innovation management, for the same reasons cited for incremental innovations. They have, however, been embraced by quality management literature because they are a source of continuous improvements and human resource management, in that an important factor for conducting an EES is the motivation for the employees to contribute their ideas. Therefore, it is common for ESS management to be located in the human resources department.

According to Lasrado, Ari, Rizvi and Urdzik (2016), ESSs are popular in many countries in the West, such as the United States, and also in Asia and the Middle East. They believed that ESSs help companies not only achieve improvements and solve cost related problems but can also generate innovations by means of employee creativity. Moreover, in many organizations, ESSs are at the heart of the creation of a continual improvement culture. Also, directors must realize that, by supporting them, their organization will benefit in terms of the overall results (Lasrado et al., 2017), such as in employee welfare (Buech et al., 2010).

The origin of ESSs has been lost over time. According to Robinson \& Stern (1997), Willian Denny used a suggestion program in 1880 at his shipbuilding company in Scotland, so that his employees could propose ideas as to how to cut shipbuilding costs. ESSs proliferated in the United States. and, prior to World War II, nearly every large US company had adopted them (Yasuda, 1991). Toward the end of the 1940s, the American suggestion system was transferred and adapted for Japanese companies, most notably Toyota, which implemented its renowned Toyota Production System in 1951 (Yasuda, 1991) in which ESS is one of its components. Entities such as the Japan Human Relations Association (JHRA) and the US National Association of Suggestion Systems (NASS) were prominent in popularizing these systems.

Owing to the large number and wide variety of ESSs, there were attempts to classify them. Schuring and Luijten (2001) broke them down into two types: conventional systems and systems categorized as kaizen. The former was also called Western or US systems, while the latter were referenced as the Eastern or Japanese. These titles neither reflect current reality nor the common origins, the aforementioned industrial improvement. Therefore, for the purposes of this article, the Barbieri, Álvares and Cajazeira (2010) classification, based on Brazilian company studies, will be used, namely: competitive system and participative system. The first is designed to capture employees' ideas that have a high probability of generating successful innovations, in turn encouraging workers through economic compensation. The second type, 
based on the kaizen concept, is understood as "continued improvement involving all persons, including management and laborers" (Marin-Garcia et al., 2018, p. 296).

An idea generated by a competitive ESS must go through a vertical analysis process involving a number of phases in the company to verify relevance, economic impact, implementation cost and remuneration for the originator. Employees, individually or in groups, compete with others if their ideas apply to the same end. Participative ESS dispenses with these steps, except in special cases in which implementation requires a high amount of capital investment. The logic of this system requires that the ideas be evaluated and implemented with the participation of the originator, involving no more that the immediate supervisor, using resources available in their area or department.

The motivation to generate ideas via participative ESS is collective, as an assurance there will be no layoffs in times of crisis, profit sharing, professional development for all, health insurance, etc. This is important since it fosters a more collective and collaborative context. Le et al. (2020) highlighted the crucial role of collaborative culture in facilitating a positive climate for knowledge sharing and innovation. In turn, Buech et al. (2010), based on an empirical study, showed that there is evidence of the importance of employee well-being for the success of ESS. The motivating argument is that, if a company is doing well, the employees also benefit, and there are concrete reasons to support this belief. Therefore, it is necessary for a company to have credibility among its employees and a reputation in the community, which is something acquired over the years.

\section{Method}

To attend the research purpose, (i.e., analyze how Horizontal Innovation enables a company to produce radical and incremental innovations, making it ambidextrous), a case study was conducted at the company, Brasilata S.A. Embalagens Metálicas, a steel packaging production company. This research strategy was appropriate, because it is a study of an exploratory nature, since it concerns a representative case, selected considering theoretical sampling.

\subsection{Unit of analysis}

Companies that have a high-performance idea system (i.e., more than 12 ideas per employee per year) are rare. Robinson and Schroeder (2014), in their book, mentioned only 32 companies with such a system: 19 in the USA, 8 in Europe, 4 in Asia and only one in Brazil, 
Brasilata. This latter case is recognized as an innovative enterprise, despite being engaged in a mature manufacturing sector. One of the case's innovative characteristics is its suggestion system, a topic central to the research, and is one of the best in the world in its business field (Robinson and Schroeder, 2009, 2016).

Brasilata S/A Embalagens Metálicas is 100\% Brazilian capital, employing nearly 1,000 employees, at four units in different states. It was founded in 1955, in São Paulo, under the name, Industry and Trade of Stamping Brasung Ltda. The steel can sector in Brazil, is scattered and highly competitive with over 40 companies of varying sizes. One of the sector characteristics is specialization by type of container: cans for food and those for chemical products. Brasilata has specialized in containers for chemicals, especially to package insecticide.

In addition, according to Yin (2015), the case study is an empirical investigation, recommended to investigate contemporary phenomena, within its real-life context, when the limits between the phenomena and the context are not clearly defined. Also, Eisenhardt (1989) showed that the case study enables understanding of concrete situations in their complex dynamics, to confirm or modify theories. The case study is an exploratory study because knowledge of one of the topics, Horizontal Innovation, has not been used to date with the significance given herein.

Is important to highlight that case studies are generalizable to theoretical propositions, not to populations or universes. In this sense, the expansion and generalization of theory and propositions are sought by means of analytical generation, instead of statistical generalization (Bauer \& Gaskell, 2008). The value of this case stands out as representative and exemplary, enabling comparisons and contrasts with cases for future analysis.

\subsection{Data collection}

The data gathering instruments used were questionnaires, interviews, documents and prior studies conducted at the firm. Given its many peculiarities, the Brasilata case has been studied and covered in several papers, some of which have been published by the FGV Innovation Forum, which approached different aspects of this company's management but did not specifically focus on Horizontal Innovation.

A questionnaire (see Appendix I) was used based on an innovation model from the FGV/EAESP Innovation Forum (Vasconcelos, 2015; Di Serio et al., 2016). The Forum proposed an innovative organization diagnostic model, including five innovative organization 
competencies: (1) Leadership and Strategy, (2) Internal Innovative Millieu, (3) Personnel, (4) Innovative Processes and (5) Results. The questionnaire used had 50 questions, namely: 5 questions on Leadership and Strategic competence, 17 concerning Internal Innovative Milieu; 4 on Personnel competence; 13 regarding Innovative Process competence; and 11 about Results competence. Company documents were also consulted focusing on ESS and the innovations presented by the interviewees.

The interviews were conducted among participants from Brasilata intentionally selected according to Creswell (2010, p.212) recommendations, which, in a qualitative study, intentional selection best helps the researcher understand. Therefore, 18 members of the upper hierarchy of the company were interviewed, as shown below in Table I. All had made their careers at the company; of the 18, 12 had begun as interns, and, therefore, Brasilata had been their sole employer.

\section{Table I}

Interviewee descriptions

\begin{tabular}{cc}
\hline Quantity & Positions \\
\hline 4 & Executive directors \\
\hline 10 & Managers \\
\hline 2 & Corporate coordinators \\
\hline 2 & Researchers (responsible for implementation at the R\&D Center) \\
\hline
\end{tabular}

Source: prepared by the authors

All interviews were recorded with the participants' authorization and transcribed. All transcriptions (18) were submitted to the participants, 17 of which were approved with no changes, and only one suggested a formal alteration, which was performed. Each interview took approximately one hour. The interview protocol was prepared taking the Creswell (2010 pp. 214-216) and Yin (2015, pp. 114-116) suggestions into consideration (see Appendix II). The interviews comprised an unstructured part, where those interviewed freely commented on their professional lives, stressing their experiences at Brasilata. The second phase was structured. Some innovations were shown, and the participants were asked why a company in a mature industrial sector had consistently achieved radical innovations. The final phase was semistructured, and the interviewees could express their opinions freely.

The triangulation (Yin, 2015) for external validation was carried out by analyzing internal and external documents on Brazilian sheet steel and the steel can market, patents, 
awards received, customer surveys and records of operation of the simplification project, in terms of ideas suggested, accepted, rejected, or implemented. The number of patents granted in several countries and the awards received, particularly for innovation, are external recognitions that have proven the continued production of innovations, not only in terms of products and processes, but also in management. The analysis of these documents shows the growth of the company's share in the Brazilian steel can market since 1995, as shown in Figure 1. Formal customer surveys were also analyzed in the context of the ISO 9001 management quality standard, supported by internal documents.

\section{Results}

Brasilata growth over the last three decades, compared to Brazilian market evolution, was vigorous. In 1995, the company grew organically to become a leader in the non-integrated can producer market. In 2020, it retained $15 \%$ of the overall steel can market in Brazil, and 35\% of paint and chemical product cans, in which it is for the most part engaged. In 2020, gross revenue was R \$ 815 million (US\$ 158 million) and net sales, R\$ 595 million (US\$ 115 million). Despite belonging to a mature sector, it has consistently been acknowledged as one of the most innovative companies in Brazil (Robinson \& Schroeder, 2016, p.24).

The strategic positioning of Brasilata has been to seek growth through innovation. In 2008, it won the FINEP Large Company Innovation Award, and, for five years running (2009 to 2013), from among 20 companies, it was considered one of the most innovative companies in Brazil by the business publication, Época Negócios. Several type B radical innovations i.e., those that change the competitive base, creating a new competitive position or niche in the established field (Gundling, 2000), have been implemented, beginning in 1995 and continuing to date; details follow.

Monitoring of steel can production progress can be made to a fair degree of precision, based on consumption of steel sheets for their production. Taking the 1995 to 2020 period, Figure 1 indicates in a comparison of normalized indices.

The data depict a significant reduction in the consumption of steel cans in Brazil during the above period, indicating that the steel can sector is in a mature and declining phase. However, Brasilata recorded steep growth for the period, over three times the rate of the Brazilian market. This advance was exclusively organic, not involving any mergers or acquisitions. 


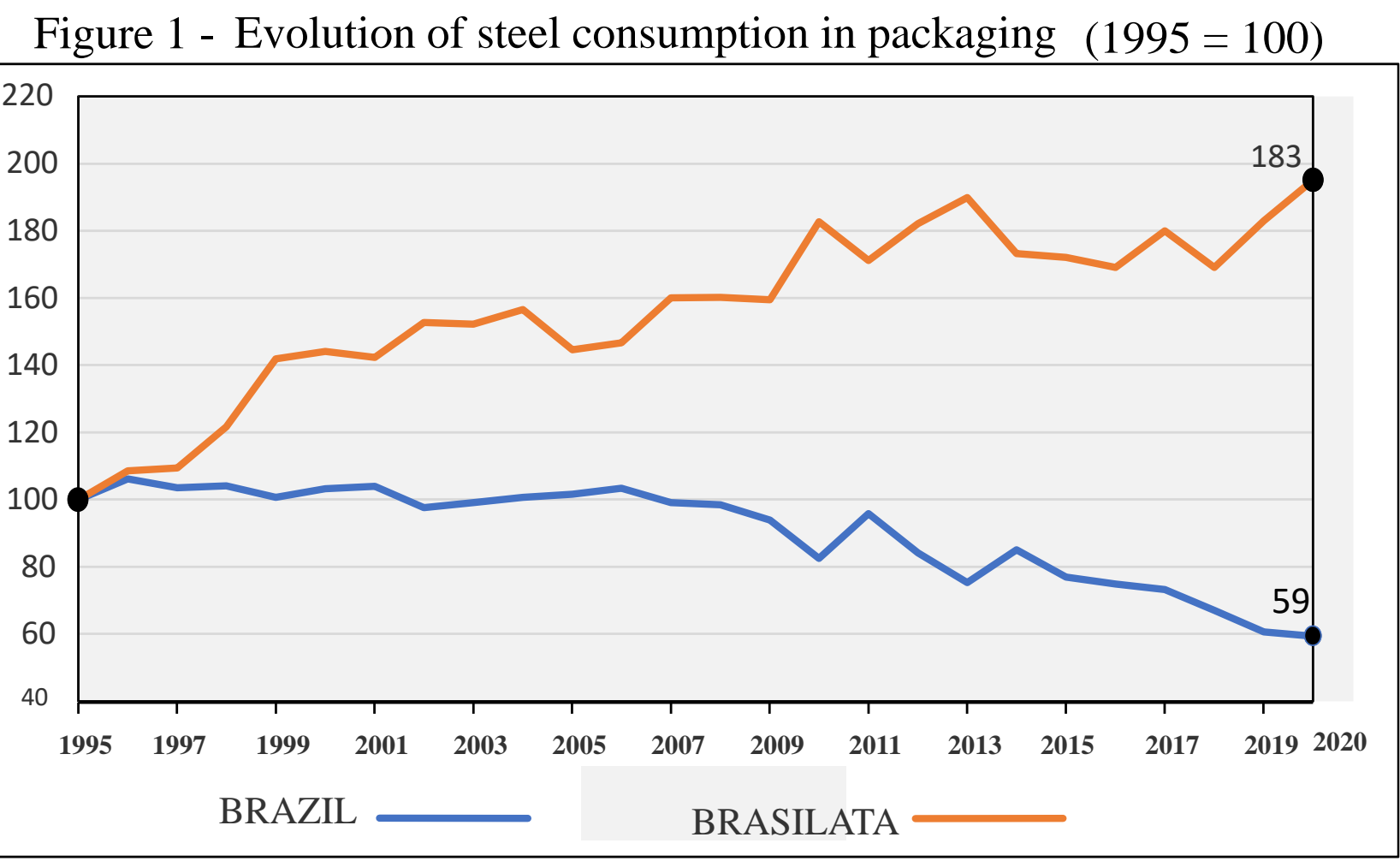

Source: Based on data from the National Union of the Metal Stamping Industry

In 1987, Brasilata implemented an ESS called the Simplification Project, based on the Toyota system. In 2012, 25 years after introduction of this project, the company had tabulated over one million ideas. In 2020, the system turned out close to 58,000 ideas, i.e., nearly 58 ideas per employee. Those interviewed were unanimous in affirming the Simplification Project had culminated in the creation of an innovative environment that enabled the company to become an innovator and win the awards cited.

The case of the palletizer innovation occurred at the beginning of the Simplification Project, in 1987. One of the cans that were very popular at the time was for edible oil, containing $900 \mathrm{ml}$. At the end of the production line, the cans were palletized in ten layers. The operator sent an idea stating that the pallet could support another layer of cans. The technicians were surprised, but, when they checked, they saw that it would really be possible to accommodate another layer. Investigations led to the conclusion that the equipment was of Italian origin, and, in Italy, a can of oil had a volume of 1 liter. Of course, where ten layers of 1-liter cans were originally accommodated, eleven layers of $900 \mathrm{ml}$ cans would fit. The change allowed an automatic gain for the company, in reduction of freight cost equivalent to US\$ 100 thousand per year. However, as, after some time, all other can manufacturers started using pallets with 
one more layer, the annual savings reached a value close to US\$ 1 million, considering the entire Brazilian market (Alvares, 2017).

When the company began producing round paint cans, its first radical innovation, type B, was the Plus Closure, in 1996, even though it still did not have a structured R\&D center. Its technological area was the factory floor, and all workers took part in some way by means of the idea mining system (Alvares et al., 2004). A year earlier, the company had created a development department and assigned an experienced project designer and the best company toolmaker to it (both interviewed for this study). This area, which maintained constant contact with the production area, was the embryo of the formal R\&D center, only inaugurated in 2014 . Prior to this, there had been only this small department and the ESS.

According to the studies mentioned above, Brasilata has an extensive collection of type B radical innovations, which, according to the Grundling (2002) classification, has changed the competitive base in the industry. The following are some of the product, process and management innovations chosen that fit into this classification.

The main radical product innovations and respective years are the Plus Closure (1995); Biplus Closure (1998); Ploc Off Closure (2002) and 18-liter dangerous products container (2010). All of them considered type B innovations, according to the Gundling (2000) classification. Biplus Closure, for instance, is based on a mechanical lock that is not an improvement on the friction closure (the world standard at the end of the validity of its patents), but rather a radical innovation (Gundling, 2000), since it changed the industry's competitive base for steel can packaging. This closure is expected to become the world standard for paint cans once its patents expire, just as happened with friction closure. In 2013, this innovation achieved the mark of one billion cans sold.

This success is due to three advantages: i) it is nearly three times more resistant than friction closure in relation to internal pressure, impact, blows and falls; (2) it is easier to open and close, while at the same time it hinders violation of the contents; (3) it results in a saving in materials, ranging from $19 \%$ to $25 \%$, reducing the use of natural resources. The positive economic impacts are high for the company: the patent alone was valued at US\$ 10 million.

As analyzed in the next section, the idea of the Biplus Closure arose from a technical assistant, as part of the Simplification Project. In Brasilata's ESS, one of the more outstanding radical production process type B innovations is the ultraviolet (UV) drying method used in the paint can lithography. One of the processes in the can production is the lithographic printing on steel sheets. The process presupposes the application of paints and varnishes that need to be 
treated at a temperature that reaches $200^{\circ} \mathrm{C}$. UV drying provides enormous advantages, including power cost reduction, less physical space (90\%) and improvement of the quality system. In conjunction with the manufacturers, Brasilata has developed special paints with UV drying. Some of these manufacturers were multinational companies, which developed on a global scale through Brasilata. This was possible because Brasilata was already well known as an innovator.

The Plus Closure was born from the idea of a designer. The new design was presented to the CEO, who immediately authorized the creation of the tooling to carry out the tests. These gave excellent results. The Biplus Closure was conceived by a technical assistant when visiting a store where the paints were colored. The Closing Ploc Off was suggested by an accountant who was looking for an airtight closure for a powdered milk can. Amazingly, the idea arose when an accounting clerk saw the Biplus Closure! She commented that, with minor modifications, it would make a handy container for several cooking ingredients they used (Robinson \& Schroeder, 2014 p.21).

The Simplification Project stands out among the radical management innovations. This has been the subject of frequent studies, not just in Brazil, but abroad as well, as can be seen in Robinson and Schroeder (2014). Another radical corporate management innovation is the Vacation Bank. The company has a policy in place to avoid layoffs, at all times managing lower demand in periods of crisis by granting mass vacations, thereby maintaining its personnel, and, as a result, its production capacity following crises. However, the 2008 world crisis took on grand proportions, and large Brazilian companies announced huge layoffs.

At the time, anticipating vacations was not allowed by Brazilian labor law, which could give rise to a liability. No Brazilian company adopted it, preferring layoffs. Brasilata was the first to adopt this alternative procedure in Brazil, keeping its staff and gaining a large market share when demand rose sharply after the crisis had passed. In 2020, 12 years later, due to the COVID 19 pandemic crisis, the Brazilian government changed the former labor law, allowing companies to grant early vacations to their employees.

Brasilata initially extended widespread vacations; however, the vacation inventory ran out in a short time. The company then decided to bring forward unearned vacation time, creating the Vacation Bank. One calculation indicated that this vacation time maneuver in one year enabled it to offer one-month vacations to nearly $20 \%$ of its personnel, for several consecutive months. After six months, the market began to recover, and Brasilata was the only company that had not made anyone redundant and there were no vacations left to extend. The company, 
with its normal capacity expanded could meet the abnormally increased demand, winning over a large slice of the market.

Thus, considering such moments in Brasilata's history, it is possible to highlight the crucial role of the Simplification Project, its ESS, in generating a high volume of ideas. Moreover, as such ideas were the raw material for a series of innovations, such as those that are the focus of analysis in this research, the radical innovations, all type B (Gundling, 2000), referring to Plus Closure, Biplus Closure, Ploc Off Closure and 18-liter dangerous product container (2010); and the UV drying method and Vacation Bank processes.

The five competencies of an innovative organization observed in Brasilata are presented in Table 2. These competencies are based on the innovative organization diagnostic model devised by the FGV Forum on Innovation, as mentioned in Section 3. As can be seen, the interviewees presented highly favorable assessments of the competencies, which, according to the Forum model, indicate maturity of an innovative organization.

The total score of 903 is located in the maximum score range (from 851 to 1000), reflecting that, as an innovative organization, Brasilata has proactive, refined, innovative foci disseminated by continuous use, sustained by ongoing and fully integrated learning.

\section{Table II}

Innovative organizational diagnostics applied in the brasilata case

\begin{tabular}{lccc}
\hline \multirow{2}{*}{ Dimensions } & \multicolumn{1}{c}{ Points } & $\%$ \\
\cline { 2 - 4 } & Possible & Obtained & $92.8 \%$ \\
\hline 1. Leadership and strategy & 120 & 111.4 & $91.6 \%$ \\
\hline 2. Internal innovator milieu & 200 & 183.2 & $95.9 \%$ \\
\hline 3. Personnel & 80 & 76.7 & $93 \%$ \\
\hline 4. Innovative processes & 200 & 186 & $86.7 \%$ \\
\hline 5. Results & 400 & 346.5 & $90.3 \%$ \\
\hline TOTAL & 1000 & 903.8 & \\
\hline
\end{tabular}

Source: Data from empirical study.

For purposes of comparison, the results found in this study are contrasted against those found in the Baraldi et al. (2016) study, comprising 93 companies from the São Paulo Management Excellence Institute and the Brazilian Quality Foundation. The methodology 
adopted by the author was the same as in the Forum questionnaire. The study used the same model, but applied 35 questions instead of 50, and did not make the percentages in the results available. It is notable that the Brasilata percentages are higher than those of the study in Internal Innovator Millieu, Personnel and Innovative Processes for which Baraldi et al. (2016) showed that there is statistical support for the positive influence on results.

\section{Table III}

Comparison of brasilata and IPEG results

\begin{tabular}{lcc}
\hline \multicolumn{1}{c}{ Dimensions } & Brasilata & IPEG \\
\hline 1. Leadership and strategy & $92.8 \%$ & $87.4 \%$ \\
\hline 2. Internal innovator milieu & $91.6 \%$ & $79.2 \%$ \\
\hline 3. Personnel & $95.8 \%$ & $84 \%$ \\
\hline & & \\
4. Innovation Processes & $93 \%$ & $69.6 \%$ \\
\hline
\end{tabular}

Source: Prepared by the authors.

The use of the questionnaire before the interview enabled determination of the significance that the interviewees conferred to the question under analysis (Creswell, 2010). The results indicate that the participants clearly perceive Brasilata as an innovative organization (Vasconcelos, 2015; Di Serio et al., 2016).

It should be emphasized that all the interviewees from the upper management have been with the company a long time because the company prioritized its internal personnel roster when it comes to promotions, which favors seniority, and follows the management model recommended by Alvares, Barbieri and Machado (2004). The employment time of those interviewed was, on average, 23.9 years. The shortest time was 18 years and the longest, 41 . These data confirm the long-term employment relationship that Brasilata maintains with its workers and the importance given to the length of time with the company in forming a management team, confirming Buech et al. (2010) observations regarding the importance of employee welfare in the success of ESS. 
All 18 interviewees affirm that Brasilata is an innovative organization. Factors mentioned as arguments include its external recognition and internal consultation. Some statements supporting these arguments are:

The Market sees Brasilata as an innovative organization. Yes, Brasilata is an innovator, and I was even surprised at the repercussions. After all, we are a B2B company, which is not known by the public at large, but many people know that we are an innovative company. (Director 2 Interviewee)

There hasn't been a year that the company hasn't talked about a new product launch or making an innovation to an existing product. Whenever there are innovation events (innovation days), Brasilata is always very well received and the companies always make sure to call us. (Manager 2 Interviewee)

I completely agree that Brasilata's innovation has been in the company's DNA ever since the implementation of Japanese techniques in the 1980s. It transcends people; it is part of the organizational culture. (Director 1 Interviewee)

The interviewees also agreed that the innovations at the company increased its competitiveness, and stressed reasons such as:

They offered a container differential and many of them resulted in gains (lower cost) which in turn were shared with the clients. When an innovation also results in lower costs, it is unbeatable. (Manager 3 Interviewee)

There has been a great deal of return, especially when just analyzing the Plus line. It is what has sustained Brasilata during a very difficult time. The situation really was not one of the best. It provided a financial return because of the gains in raw materials. (Researcher 1 Interviewee).

All of them recognized that the radical product and process innovations were responsible for the company's increased productivity, and subsequently led it to a leadership position in the market in which it is engaged. According to the great majority of those interviewed, the Plus Closure was the most important of all the product innovations, because it introduced an improved product at a lower cost in a large market. One argument found among those interviewed is that the innovations happened despite the company working in a mature market, which enabled growth of sales during times of difficulty without lowering prices and capturing new markets.

The company demonstrated that it is possible to innovate in a mature market. The Biplus revolutionized paint cans, whose paint content color is mixed at the sales point. (Manager 4 Interviewee).

Without them, it would be difficult to survive. They certainly increased competition. Many of these products are responsible for a good part of sales. For example, the Biplus took off right away in the paint market where paints are mixed at the sales point. (Manager 8, Interviewee) 
Out of the 18 respondents, 17 affirmed that there was no competition among radical innovations, rather cooperation. One single respondent commented that there would have been competition if the resources had been excessive, but also takes into consideration that incremental, radical innovations are complementary.

The only way to compete is if you overspend. Incremental innovations are fundamental for the implementation of radical innovations. (Director 2)

The fact that we are used to incremental innovations, enables an open-minded attitude toward change, and consequently new radical innovations arise. (Manager 6)

Although the Simplification Project in relation to the internal suggestion program is directed toward incremental innovations, it does not jeopardize radical ones. Instead, the interviewees argued that the program provided ideas for the implementation of radical innovations and insights for new products. For instance, the Biplus and Ploc Off closures were cited as developments based on Simplification Project ideas.

Certainly, to produce innovations, the Simplification Project played an important role. Whenever a process is modified, incremental innovations were important and helped the radicals. Ploc Off, for example, went through many changes until reaching the final form. The insight to produce the Ploc Off came from an ordinary employee with the idea of producing a can for food using the concept of the Biplus used for paint cans. (Director 2)

The idea of the Biplus was brought up by a technical assistant. (Manager 9)

Ploc Off came from an insight into the Simplification Project, and only then was it developed with the support of R\&D. (Manager 8).

In the next section, such innovations are evaluated based on the analysis of the interviews and questionnaires applied in the field research and compared with the literature.

\section{Discussion}

Based on the fact that those interviewed believed that incremental innovations are in favor of radical innovations, contrary to authors such as Negroponte (Peters, 1998), but in line with authors such as Lawson and Samson (2001), Tushman and O’Reilly III (2004), Castellaci (2008); Scandelari and Cunha, (2013), Kortmann et al. (2014), Kortmann (2015), Tidd and Benssant (2015), Cooccia (2017), Kang and Hwang (2019), who analyzed the capacity of organizations that systematically implement incremental, radical innovations, thereby operating as ambidextrous organizations,. 
The interviewees stated that the large number of incremental ideas was exactly what made the company innovative, capable of producing innovations of all types and sizes. In their opinion, the generation and implementation of ideas stemming from the people in the organization, or what is referred to in this article as Horizontal Innovation, was responsible for the creation of the internal innovative environment (one of the five competencies of an innovative organization) recommended by the FGV/EAESP Forum. This enabled the transformation of a company operating in a mature and declining sector into an ambidextrous innovative organization.

Therefore, taking into consideration the company's background, use of questionnaires from the EAESP/FGV Innovation Forum, internal and external documentation analyzed and interviews conducted, the study identified that:

(1) Brasilata is an innovative company that implements incremental, radical innovations systematically;

(2) the innovations identified encompass innovations in products, processes and also as management innovations;

(3) the company has an ESS program in place modeled on the basis of kaizen (Simplification Project), which enables the gathering of innovative ideas from all employees, generating thousands of horizontal, radical as well as incremental innovations;

(4) the Simplification Project is important in establishing an internal innovation culture, referred to here as internal innovator milieu;

(5) the company can be described as ambidextrous according to the Tushman and O'Reilly III concept (2004), because it has achieved competitive advantages, simultaneously producing radical and incremental innovations in a balanced way, as described by Scott (2014) and Kang and Hwang (2019).

\section{Final remarks}

The purpose of this study was to analyze how Horizontal Innovation enables a company to produce radical and incremental innovations, making it ambidextrous. A company can become capable of achieving incremental innovations to increase operational efficiency as well as radical innovations that assure strategic positioning in the sector in which it is engaged. 
The case investigated, Brasilata, has systematically produced radical innovations, which change the company's competitive base, and also its incremental innovations that increase its competitiveness. Using questionnaires and conducting interviews with 18 members of the company's key management made it possible to analyze the introduction of radical innovations in products that significantly increase their market share, as well as lead to a radical management innovation. The interviewees, who, on the contrary, confirmed that they complemented each other owing to the internal innovation culture, soundly rejected the controversy regarding competition between incremental innovations and radical ones. The Simplification Project was understood as an important component of the company's internal innovative milieu and the main source of Horizontal Innovation.

The case study has shown that the systematic search for innovation based on all employees has enabled the company to become ambidextrous. In other words, the case demonstrates through an exemplary case how the encouragement of participation of all employees - especially those involved in the production process - in the generation of ideas can create Horizontal Innovations, a concept proposed in the paper, and that such innovations can be not only incremental but radical.

This paper reinforces the debate that defends innovative ambidexterity (i.e., that an organization can achieve radical and incremental innovations at the same time) as a source of competitive advantage, and describes an exemplary case for insights into how a culture that stimulates ambidexterity can influence the ambidextrous behavior of employees, which in turn generates performance in terms of suggestions and implementations of both radical and incremental innovations. The paper creates and defines the concept of Horizontal Innovation: a type of innovation that originates from all employees, usually stemming from an ESS. Also, the study demonstrates, based on continual ESS operations, how a company can achieve ambidexterity and systematically produce incremental, radical products and processes.

One of the limitations of the referenced study is the fact that it is single case, making it impossible to generalize at first. However, it is important to highlight that the expansion and generalization of theory and propositions were sought by means of analytical generation, instead of statistical generalization (Bauer \& Gaskell, 2008). Thus, the value of this case stands out as an exemplary one, enabling comparisons and contrasts with those for future analysis.

Therefore, as a suggestion for future studies, an analysis of other company cases that adopt a system that gathers ideas from all employees (Horizontal Innovation), is recommended to attempt to contrast findings and generalize (or not) whether the system is capable of 
promoting internal innovation culture (Internal Innovative Millieu) making organizations ambidextrous. Another suggestion for future studies is the creation of a framework that can be proposed to evaluate other companies, delineating the number of radical innovations per year from an ESS, the number of patents, and evaluating the company culture.

The authors intend to replicate the study in other companies that adopt high performance idea systems. It will not be an easy task, at least in Brazil, where, after a year of research, only one more company with more than 12 ideas per employee per year was found. This, therefore, represents a path for research with a new, unique, exemplary case. An alternative would be to collaborate with researchers from other countries, particularly the USA or in Europe. Future research may also try to understand the antecedents of Horizontal Innovation, whether it is reinforced or inhibited by contingency factors, and which are the most important. Another important point in the debate is the role of organizational culture in building a fertile space for implementing Horizontal Innovation. Thus, companies interested in fostering this type of innovation would have more instruments to seek to make it viable.

The Horizontal Innovation concept, as innovation based on the people in the organization, values and encourages people to being a fundamental source of success for the organization. Therefore, new studies are highly appropriate to enable development of the Horizontal Innovation concept. Regarding its main contributions, this paper strengthens the literature stream that advocates the complementarity of radical and incremental innovations, and expands the types of innovation, introducing the concept of Horizontal Innovation. A new type of innovation is proposed and described, reinforcing the value of the ESS as a relevant management tool. This case allows for comparisons and contrasts with others for benchmarking of best practices. Also, the paper contributes to the practice by providing evidence of how to obtain competitive advantages even in a mature industry through Horizontal Innovation, reinforcing the advantages of an innovative culture that fosters idea sharing among all employees. The research also highlights for managers the potential of implementing an ESS as a means of achieving not only incremental innovations, but also radical ones.

\section{References}

Alvares, A.C.T. (2017) Inovação Horizontal: ambidestria e sustentabilidade. 'Forum FGV Inovação. Available at: https://docplayer.com.br/159963064-Inovacao-horizontalambidestria-e-sustentabilidade-antonio-carlos-teixeira-alvares-2-inovacoes-radicaisincrementais-e-ambidestria.html (accessed at 12 November 2021). 
Alvares, A. C. T. (2017-2). Horizontal Innovation versus ambidexterity. The Canmaker Magazine. Available at: https://www.canmaker.com/online/horizontal-innovationversus-ambidexterity/ (accessed at 12 November 2021)

Alvares, A. C. T. (2016) Innovation has more to do with culture than money. The Canmaker Magazine. Available at: https://www.canmaker.com/online/?s=Innovation+has +more+to+do+with+culture+than+money (accessed 01 June 2021)

Alvares, A. C. T., Barbieri, J. C. \& Machado D.D. (2004), O Caso Brasilata, Barbieri, J. C. (Ed.), Innovative Organizations: Brazilian case studies, FGV Editora, São Paulo, SP, pp. 77-111.

Barbieri, J. C. \& Alvares, A. C. T. (2016) Sixth generation innovation model: description of a success model, Revista de Administração e Inovação, Vol. 12 No. 2, pp. 116-127. https://doi.org/10.1016/j.rai.2016.04.004

Barbieri, J. C. \& Alvares, A. C. T. (2016) Continual Innovation Model; an example of a concrete case, in SIMPOI FGV/EAESP, São Paulo, pp. 1-17

Barbieri, J. C., \& Álvares, A. C. T. (2005) O retorno dos sistemas de sugestão: abordagens, objetivos e um estudo de caso. Cadernos EBAPE, Vol. 3, No special, pp. 01-17. https://doi.org/10.1590/S1679-39512005000500012

Barbieri, J. C. \& Alvares, A. C. T. (2004), Inovações nas organizações empresariais, Barbieri, J. C. (Ed.), Innovative Organizations: Brazilian case studies, FGV Editora, São Paulo, SP, pp. 41-63.

Barbieri, J. C., \& Álvares, A. C. T. (2002) Corporate innovative means: concepts, models and cases. Revista IMES Administração, Vol. 56, pp. 34-43.

Barbieri, J. C., Álvares, A. C. T., \& Cajazeira, J. E. R. (2009). Gestão de ideias para inovação contínua. Bookman Editora, São Paulo, SP.

Bauer, M. W., \& Gaskell, G. (2017). Qualitative research with text, image and sound: a practical manual. Vozes, Petrópolis, Brazil.

Bruneel, J, Velde, E. V., Clarysse, B \& Paul G. (2012) Improving the success of radical innovation projects within established firms: engaging employees across different hierarchal levels, Technology Analysis \& Strategic Management, Vol. 24, No. 9, pp. 951-965. https://doi.org/10.1080/09537325.2012.718667

Buech, V., Michel, A. \& Sonntag, K. (2010). Suggestion systems in organizations: what motivates employees to submit suggestions? European Journal of Innovation Management. Vol. 13, No 4, pp. 507-525. https://doi.org/10.1108/14601061011086311

Chen, K. Y., Hsiao, C. H., Chen, P. Y., \& Lee, C. F. (2018) The relationships among different types of market knowledge, ambidextrous learning, and different types of innovations, in Proceedings of International Academic Conferences. International Institute of Social and Economic Sciences, 
Creswell, J. W. (2010), Research Project, Penso Editora, São Paulo, SP.

Edelman, B., \& Eisenmann, T. R. (2011). Google Inc, Harvard Business Review, Vol. 77, pp. 96-108.

Economic Cooperation \& Development Organization and Statistical Office of the European Communities Oslo Manual 2018: guidelines for collecting, reporting and using data on innovation. Paris: OECD, EUROSTAT, 2018.

Eisenhardt, K. M. (1989) Building theories from case study research, Academy of management review, Vol. 14 No. 4, pp. 532-550. https://doi.org/10.5465/amr.1989.4308385

Gibson, C.B., Birkinshaw, J.: The Antecedents, Consequences, and Mediating Role of Organizational Ambidexterity. Academy of Management Journal, vol. 47, 209-226 (2004) https://doi.org/10.5465/20159573

Gundling, E. (2000), The 3M way to innovation Kodanska America, New York, NY.

Heath, C \& Heath D. (2010) The Turnaround; simple ways to manage big transformations. Best Business, Rio de Janeiro, RJ.

Kortmann, S. (2015), The mediating role of strategic orientations on the relationship between ambidexterity-oriented decisions and innovative ambidexterity. Journal of Production Innovation Management, Vol. 32, No. 5, pp. 666-684.

https://doi.org/10.1111/jpim.12151

Kortmann, S., Gelhard, C., Zimmermann, C. and Piller, F. T. (2014) Linking strategic flexibility and operational efficiency: The mediating role of ambidextrous operational capabilities, Journal of Operations Management, Vol. 32, No. 7, pp. 475-490. https://doi.org/10.1016/j.jom.2014.09.007

Koryak, O., Lockett, A., Hayton, J., Nicolaou, N., \& Mole, K. (2018), Disentangling the antecedents of ambidexterity: Exploration and exploitation, Research Policy, Vol. 47, No. 2, pp. 413-427. https://doi.org/10.1016/j.respol.2017.12.003

ISO - International Organization for Standardization (2015). ISO 9001:2015. Quality management systems - Requirements. Geneve, 2015.

Lasrado F., Ari M., Rizvi A., Urdzik C. (2016) Critical success factors for employee suggestion schemes: a literature review. International Journal of Organizational Analysis, Vol. 24, No 2, 2016. https://doi.org/10.1108/IJOA-04-2014-0753

Lawson, B. \& Samson, D. (2001), Developing innovation capability in organizations: a dynamic capabilities approach, International Journal of Innovation Management, Vol. 5, No., 03, pp. 377-400. https://doi.org/10.1142/S1363919601000427

Le, P.B., Lei, H., Le, T.T., Gong, J. \& Ha, A.T. (2020), Developing a collaborative culture for radical and incremental innovation: the mediating roles of tacit and explicit knowledge 
sharing, Chinese Management Studies, Vol. ahead-of-print No. ahead-ofprint. https://doi.org/10.1108/CMS-04-2019-0151

March, J. G. (1991), Exploration and exploitation in organizational learning, Organization science, Vol. 2, No. 1, pp. 71-87. https://doi.org/10.1287/orsc.2.1.71

Marin-Garcia, J. A., Tarraga, A. M. \& Mascarell, C. S. (2018), Kaisen philosophy: the keys of the permanent suggestion systems analyzed from workers' perspective, The Total Quality Management Journal, Vol. 30, No. 4, pp 296-320. https://doi.org/10.1108/TQM-12-2017-0176

Melton, H. \& Hartline, M.D. (2015), Customer and employee co-creation of radical service innovations, Journal of Services Marketing, Vol. 29 No. 2, pp. 112 123. https://doi.org/10.1108/JSM-02-2014-0048

Paiva, E. L. (2019) Ambidexterity and coevolution in operations: integrating theory and practice, Revista de Administração de Empresas, Vol. 59, No. 2, pp. 144-148. https://doi.org/10.1590/S0034-759020190206

Pertusa-Ortega, E. M., Molina-Azorín, J. F., Tarí, J. J., Pereira-Moliner, J., \& López-Gamero, M. D. (2020). The microfoundations of organizational ambidexterity: A systematic review of individual ambidexterity through a multilevel framework. BRQ Business Research Quarterly, https://doi.org/10.1177/2340944420929711

Peters, T 1998. O círculo da inovação: você não deve evitar o caminho para o seu sucesso. São Paulo, Editora Harbra, pg. 26.

Robinson, A. G., \& Schroeder, D. M. (2014). The idea-driven organization: unlocking the power in bottom-up ideas. San Francisco, Berrett-Koehler Publishers, Inc.

Robinson, A. G \& Schroeder, D. M. (2009) The role of front-line ideas in lean performance improvement, Quality Management Journal, Vol, 16, No. 4, pp. 27-40. https://doi.org/10.1080/10686967.2009.11918248

Robinson, A. G \& Schroeder, D. M. (1997) Corporate Creativity: How innovation and Improvement Actually Happen, Barret-Koeler Publisher, Vol 16, pp. 27-40.

Scandelari, V. R. N \& Cunha, J. C. (2013) Ambidexterity and social environmental performance in the electrical/electronic sector. Revista de Administração de Empresas, Vol. 5, No. 3, pp. 183-198.

Scott, N. (2014) Ambidextrous strategies and innovation priorities: adequately priming the pump for continual innovation, Technology Innovation Management Review, Vol. 4, No. 7, pp. 44-51.

Silveira-Martins, E., \& Rossetto, C. R. (2015). Ambidestria organizacional-exploração e explotação: um estudo bibliométrico nas bases de dados internacionais. Revista Gestão Organizacional, 7(2). https://doi.10.1590/S0034-75902013000200006 
Skarzynski, P., \& Gibson, R. (2008). Innovation to the core: a blueprint for transforming the way your company innovates. Boston, Mass.: Harvard Business Press.

Ternes, A. (1997) WEG, 36 Anos de História - 35 Years of History, Gráfica e Editora Pallotti: Porto Alegre.

Tushman M, \& O’Reilly III (2013), Organizational ambidexterity: Past, present, and future, Academy of management Perspectives, Vol. 27, No. 4, pp. 324-338. https://doi.org/10.5465/amp.2013.0025

Tushman M, \& O'Reilly III (2004), The Ambidextrous Organization, Harvard Business School Press, Boston.

Van De Ven, A. H., Angle, H. L., \& Poole, M. S. (2000), Research on the management of innovation: the Minnesota studies, Oxford University Press, Oxford.

Von Hippel E. (2002) Open-source projects as horizontal innovation networks - by and for users MIT Sloan School of management Working Paper 4366-02 June 2002.

Wolf, V. (2019). Ambidexterity in Service Innovation Research: A Systematic Literature Review. 14th International Conference on Wirts chafts informatik, February 24-27, 2019, Siegen, Germany.

Yasuda, Y. (1991), 40 years, 20 million ideas: the Toyota suggestion system, Productivity Press, Portland.

Yin, R. K (2015). Estudo de caso: planejamento e método. Bookmam, Porto Alegre.

\section{Exhibit 1}

Questionnaire items

\begin{tabular}{lc}
\hline QUESTIONS & Points \\
\hline I. LEADERSHIP AND STRATEGY & $\mathbf{1 2 0 . 0}$ \\
\hline 1.1. Corporate Principles & $\mathbf{2 0 . 0}$ \\
\hline 1.1 (01) The Organization is guided by the principles of Ethics, Human and Labor Rights, Diversity, & 20.0 \\
Social Responsibility, Protection of the Environment and Sustainable Development. &
\end{tabular}

\begin{tabular}{lr}
\hline 1.2. Strategic Intention for Innovation & $\mathbf{4 0 . 0}$
\end{tabular}

\begin{tabular}{ll}
\hline 1.2 (02) Innovation is part of the organizational strategy. & 20.0
\end{tabular}

1.2 (03) The objectives and goals of innovation are explained in the Organization's plans. 20.0

\begin{tabular}{lr}
\hline 1.3. Institutional Action & $\mathbf{2 0 . 0}$
\end{tabular}

1.3(04) The company is guided by the principles of sustainability in its social, environmental and economic dimensions. 


\section{QUESTIONS}

Points

1.4. (05) The Board looks at the needs of the consumer and the market, and keeps itself informed about changes in the environment.

\section{INTERNAL INNOVATIVE MEANS}

2.1. Mobilizing Leadership for Innovation

2.1 (06) Leadership encourages the engagement and mobilization of all in favor of innovation.

2.1 (07) The leadership considers that well-intentioned error is part of learning.

\subsection{Management Model}

2.2 (08) The organizational structure (communication between departments, hierarchy levels, etc.) facilitates innovation.

2.2 (09) Employees are able to solve problems and make the necessary decisions on issues generated in their day-to-day work.

2.2 (10) People are expected to bring ideas. opinions, disagree and take a stand.

2.2 (11) Communication between the various areas and levels is constant and fluid.

\subsection{Quality of Life at Work}

2.3 (12) The Organization values diversity in its staff.

2.3 (13) The Organization's working conditions (environment, infrastructure, etc.) stimulate creativity and innovation.

2.3 (14) Recognition of work is collective.

2.3 (15) The Organization has the power to make decisions close to the point of origin of the requested decision.

\subsection{Culture of Innovation}

2.4 (16) People feel empowered to take initiatives, create and innovate.

2.4 (17) There is a constant concern with passing on the Organization's values to all people, including future generations.

2.4.(18) People have a strong commitment to the Organization.

2.4 (19) People understand that risk, error and failure are part of the act of innovating, and have confidence in their own capacity to overcome them.

\subsection{Informal Internal Networks}

2.5 (20) The Organization promotes integration and free movement among different areas.

2.5 (21) The Organization encourages personal contacts among people from all areas, through mechanisms such as: internet, rotation programs, meetings, multifunctional teams, others.

2.5 (22) The Organization encourages all employees to keep themselves informed and connected with external sources of information.

\subsection{Qualification and Learning}

3,1 (23) The Organization encourages employee training and learning.

3.1 (24) The Organization has infrastructure and systems that facilitate communication among people, experimenting with ideas and sharing knowledge. 
3.2 (25) People are proud of the innovations implemented.

3.2 (26) Employees see themselves participating in the company's future.

\section{INNOVATION PROCESSES}

4.1 (27) There is a well-established planning process for the innovations that will occur in the coming years, both technological and organizational.

4.1 (28) Innovation and Improvement Projects, both successful and unsuccessful, are analyzed for lessons for future innovations.

\subsection{Capital for Innovation}

4.2 (29) The Organization objectively assesses and manages the risks of innovation in its various stages.

4.2.(30) The Organization routinely allocates its own resources for innovation.

4.3 (31) The Organization presents technology management strategies and mechanisms, from the mapping of current / future technologies to the assessment of the portfolio of technologies in use.

4.3 (32) The Organization presents strategies and mechanisms to encourage the flourishing and sharing of tacit knowledge.

\subsection{Strategic Alliances for Innovation}

4.3 (33) The company develops innovation projects in partnership with other institutions (other companies, universities. research institutes, etc.)

\subsection{Generation of Ideas for Innovation}

4.5.(34) Participation in generating ideas is open to all employees of the company.

4.5.(35) The Organization has formal mechanisms or tools to encourage the generation of ideas for innovation (suggestion systems, brainstorming meetings, idea programs, etc.).

4.5 (36) The relationship among the different areas and hierarchical levels is close, allowing the sharing of experiences and the generation of multidisciplinary ideas.

\subsection{Prioritization and Development of Innovation Projects}

4.6 (37) There is sufficient flexibility in the decision system to allow small improvement projects to be carried out quickly. projects.

4.6 (38) Organization allocates resources (people, tools, systems) for the development of innovation

\subsection{Implementation of Innovation Projects}

4.7.(39) Innovations are celebrated, from incremental to those with the greatest repercussion.

5.1.(40) In the last three years, the Organization has shown a Return on Investment above the sector average. 
5.1.(41) The Organization's market share has grown over the past three years.

\subsection{Compliance with Innovation Objectives and Plans}

5.2.(42) The Organization establishes annual Innovation goals, and has consistently met them.

5.2.(43) The Organization sets an annual target for the participation of Innovation in Net Revenue and has consistently met it.

\subsection{Results of the Innovation Process in the last three years}

5.3.(44) New or significantly improved products account for a significant portion of sales.

5.3.(45) Significant process innovations have been introduced, including methods of producing goods

and services, logistics systems, etc.

5.3.(46) Significant organizational innovations have been implemented, including management techniques, power delegation systems, etc.

5.3.(47) The innovations generated have allowed the company to enter new markets and businesses.

\subsection{Impact of Innovations}

5.4.(48) Innovations in process have increased the Organization's competitiveness in terms of Cost, Quality, Time and Flexibility.

5.4.(49) Innovations in innovation processes allow the Organization to respond quickly to consumer and market demands.

5.4.(50) A The innovations developed are eco efficient - they have reduced the consumption of inputs and the negative impacts on the environment.

Source: FGV / EAESP Innovation Forum.

\section{Exhibit 2}

\section{Interview protocol}

Interviewee name.

Date.

Initially, the interviewee was told that the interviewer should be seen as a teacher and researcher, and that, despite having worked in the company, he would issue an opinion to avoid influencing the interviewee. If the interviewee agrees, the interview will be recorded.

The interviewee was left at ease for about 15 minutes to talk about his experience at Brasilata, citing admission date, areas where he worked and experience in other companies.

Interview Questions:

1. Brasilata has been cited as an innovative organization (which systematically promotes innovations). What do you think about it? 
2. Brasilata has produced several patented innovations that have given rise to new products, including: Plus Closure; Biplus Closure; Ploc Off; an 18-liter can for dangerous products. In your opinion, of all these innovations, which was the most important and why?

3. Please comment on the importance of the others.

4. The literature cites the pioneering implementation of UV lithography technology for paint and chemical cans (UV technology cannot be used for food) as an important process innovation at Brasilata. What do you think about this?

5. Brasilata hires all its employees with an inventive function, and all are called inventors. In your opinion, does this mean that in Brasilata innovations are expected to come from everyone, or is it just internal marketing?

6. In 1987, Brasilata implemented an ideas program called the Simplification Project, which, according to the literature to date, has received more than 1 million ideas. In your opinion, was this a management model innovation that has increased the company's competitiveness?

7. Did the incremental innovations in the Simplification Project start to emerge before radical innovations?

8. Did the Simplification Project, in addition to incremental innovations, occasionally produce radical ones?

9. Did some of the radical innovations mentioned in questions 2 and 4 have the direct or indirect participation of the Simplification Project?

10. According to the literature, the ideas approved by the Simplification Project basically give rise to improvements and are incremental innovations. Do you think that the excess of incremental innovations can compete with radical ones?

Closing:

Thank you for your participation. I leave you free to express your personal opinions as to why a company belonging to a very mature sector is considered one of the most innovative in the country.

Source: The authors. 